\title{
New instruments to monitor coastal sea water masses according to European Water Framework Directive, Trophimatique project
}

\author{
Michel Répécaud ${ }^{a}$, Yves Dégrés ${ }^{b}$, Nathalie Bernard ${ }^{c}$, Jean-Pierre Allenou ${ }^{a}$, Yannick Aoustin $^{a}$, \\ Jean-Pierre Arrondeau ${ }^{c}$, Jean-François Bouget ${ }^{a}$, Karen Bucas ${ }^{a}$, Anne Daniel ${ }^{a}$, Jean-François \\ Guillaud $^{\mathrm{a}}$, Michel Hamon ${ }^{a}$, Paul Jégou ${ }^{a}$, Agathe Laes $^{a}$, Dominique Le Roux ${ }^{\mathrm{a}}$, David Le Piver ${ }^{\mathrm{a}}$, Loic \\ Quemener $^{a}$, Jean-François Rolin ${ }^{a}$, Tiphaine Rudelle ${ }^{a}, J^{2}$ acques Legrand ${ }^{a}$, Renaud Vuillemin ${ }^{d}$
}

\footnotetext{
a Ifremer. Centre de Brest BP 7029280 Plouzané - France

b nke. rue Gutenberg - Z.I de Kérandré - 56700 Hennebont - France

${ }^{c}$ Institution d'Aménagement de la Vilaine. Bd de Bretagne - 56130 La Roche Bernard - France.

${ }^{d}$ Observatoire océanologique de Banyuls/mer. BP 44. 66651 Banyuls sur mer - France
}

\begin{abstract}
:
The automated monitoring of physico-chemical parameters in the coastal zone has been using large buoys and fixed infrastructures. A better understanding of many estuaries is needed in order to fulfil the agenda and requirements of the European Water Framework Directive. In order to address the fluxes of nutrients as well as algal blooms and low oxygen events, the "TROPHIMATIQUE" project has developed a new generation of instruments able to be deployed in sea waters. The smaller size of the new instruments is intended to facilitate the maintenance. A new multi-parameter probe has been developed. The measurements of all nutrients are performed thanks to the CHEMINI flow injection analysers for nitrate, ammonia, silicate and phosphate. A sampler using similar technologies is linked. Light buoys called SMATCH are monitoring the protected zones while a new umbilical anchored buoy called MOLIT is monitoring the open sea site. The deployment in the three water masses of the Vilaine estuary (estuary, intermediate and coastal) was started in 2008. This estuary is threatened by low oxygen events. An hypoxic episode in 1983 caused huge mortality in sea life. First results in 2008 demonstrated the advantage of hourly automated measurements. Main events are described in the PREVIMER quarterly newsletter issued on a public portal (http://www.previmer.org/en/newsletter). The PREVIMER modelling project of the Bay of Biscay is using the in-situ data gathered by Trophimatique project. The TROPHIMATIQUE project involves Ifremer and nke for the technical development and the Institution d'Amenagement de la Vilaine (management institution of Vilaine river basin) ; it is funded by the French National Research Agency Ecotechnology program PRECODD and benefits from funds of Brittany Region and Ifremer.
\end{abstract}

Keywords: Chemical technology ; Computerized monitoring ; Condition monitoring ; Fluid flow measurement ; Instruments ; Performance analysis ; Performance evaluation ; Probes ; Protection ; Sea measurements 


\section{INTRODUCTION}

While the feasibility of higher frequency of measurement was demonstrated several years ago [1,2], manual sampling is still the basis for most of the assessment of the coastal zone environment. The automated monitoring of physico-chemical parameters has been done using large buoys and fixed infrastructures [3]. A better understanding of many estuaries and bays is needed in order to fulfil the agenda and requirements of the European Water Framework Directive, but manual sampling costs are a limitation. New technologies in sensors [4], improvement of scientific interpretation of long time series [6] tend to show that the next stage will include more automated measurements.

In France, the ecotechnology approach is promoted by the National Research Agency in order to mobilize R\&D on environmental matters such as monitoring. In order to address the fluxes of nutrients as well as algal blooms and low oxygen events, the TROPHIMATIQUE project has developed a new generation of instruments able to be deployed in sea waters. The smaller size of the new instruments is intended to reduce the cost and facilitate maintenance.

PREVIMER is a pre-operational service in operational oceanography with the objective to produce routine analysis and forecast of the marine environment in coastal zones at various geographical scales (from the shelf to the bay) with capabilities of zooming in specific areas of particular interest. The time scale includes both retrospectives analysis and short term forecast (from T+48 to T+144 (6 days) for waves). PREVIMER provides information in the following thematic fields covering the Channel, the Bay of Biscay and the French Mediterranean coast : Currents, temperature, salinity from surface to sea bottom, Sea state: wave height, period and energy spectrum, Primary production, Sediment transport. PREVIMER uses a range of data to validate the models: in situ real time data from a tide gauges network, real time data from a wave buoy network, data from fixed buoys such as the MOLIT buoy, TS profiles collected from voluntary fishing boats and from the semi lagrangian coastal profilers Pagode.

\section{TECHNOLOGICAL DEVELOPMENTS}

The technical solutions and bottlenecks. The instruments for the three types of water masses addressed, need to be compatible to each another and included in a metrological procedure linked to reference laboratory methods. Among the major specifications for designing the equipments: measurement at surface level and seafloor within a short time anti-fouling protection, in-situ calibration for nutrients 


\section{CHEMINI flow injection analysis instruments}

The measurement of all nutrients are performed thanks to the CHEMINI flow injection analysers for nitrate, ammonia, silicate and phosphate. A sampler using similar technologies

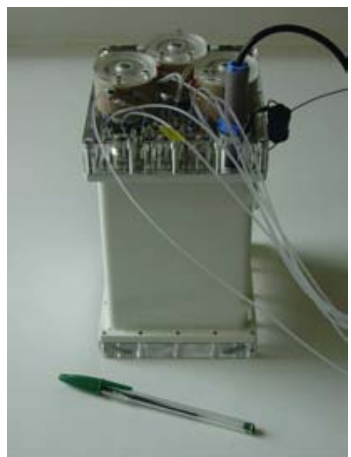

is linked to it.

Fig 1- - Chemini - Chemical analyser using Flow injection analysis.

\begin{tabular}{|c|c|c|c|c|}
\hline & Ammonium & Nitrate & Phosphate & Silicate \\
\hline $\begin{array}{l}\text { Limit of } \\
\text { detection } \\
\mu \text { mol.1 }^{-1}\end{array}$ & 0,05 & 0,5 & $0,04^{1}$ & 0,1 \\
\hline $\begin{array}{l}\text { Linearity } \\
\mu_{\text {mol. }}^{-1}\end{array}$ & $0-300$ & $0-60$ & $0-5$ & $0-200$ \\
\hline $\begin{array}{l}\text { Precision } \\
\mu_{\text {mol. }}^{-1}\end{array}$ & $3 \%$ to 5 & $2 \%$ to 2 & $4,5 \%$ to 2 & $2,8 \%$ to 5 \\
\hline Detection & Fluorimetry & Colorimetry & Fluorimetry & Colorimetry \\
\hline $\begin{array}{l}\text { Reference } \\
\text { Method }\end{array}$ & $\begin{array}{l}\text { Kérouel, } \\
\text { Aminot } \\
{[1],[2]}\end{array}$ & $\begin{array}{l}\text { Bendschneider, } \\
\text { Robinson } \\
\text { Photoréduction }\end{array}$ & $\begin{array}{l}\text { Frank et al. } \\
\text { [4] }\end{array}$ & $\begin{array}{l}\text { Mullin, } \\
\text { Riley [5] }\end{array}$ \\
\hline Publication & $\begin{array}{l}\text { Laes et al. Ir } \\
\text { prep }\end{array}$ & $\begin{array}{l}\text { Laes et al. In } \\
\text { prep }\end{array}$ & & \\
\hline
\end{tabular}

\section{Small buoys for protected areas}

Small buoys called SMATCH monitor protected zones. Their weight of $11 \mathrm{~kg}$ allows versatility of deployment. The communication may be by Iridium satellite link or aGPRS link. They have also self positioning by GPS.

A new multi-parameter probe has been developed by nke company. It is protected against biofouling and measures temperature, depth, conductivity, turbidity, dissolved oxygen, fluorescence and $\mathrm{pH}$.

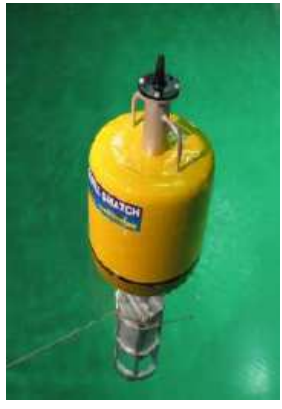

Fig.2 - - Smatch buoy

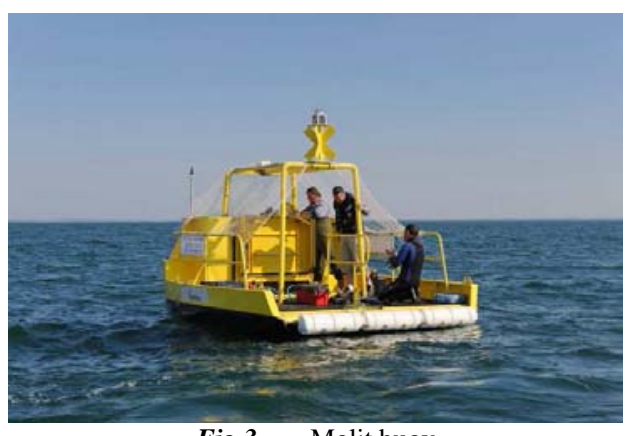

Fig.3 - - Molit buoy

The open sea monitoring: Marel Molit_buoy

A new umbilically anchored buoy called MOLIT has been designed for the monitoring of open sea site. It uses all the background and patents of the Marel systems deployed in several estuaries in France [2]. This new concept allows rather more comfortable work at sea, and this platform is also designed to be considered as an unmanned automated floating lab.

The sea water is pumped threw a pipe from the bottom of the sea and from a sub-surface position. All the water circulation is protected against the fouling by a system of chlorination between two measurements. Each 30 minutes, data from the probes are collected and logged until daily data transmission by GSM to the ground station.

\section{SITE OF DEPLOYMENT: THE VILAINE ESTUARY}

The deployment in the three water masses of the Vilaine estuary (estuary, intermediate and coastal) started in 2008. This estuary is threatened by low oxygen events (hypoxy). An hypoxic episode in 1982 caused huge mortality of sea life. Every year, the chlorophyll spring blooms are intense in the Bay of Vilaine (Fig 4), in addition the vicinity of the high flow Loire river must be considered. 


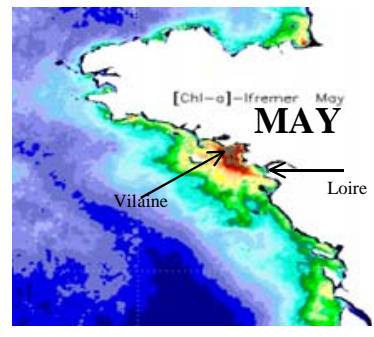

Fig 4 - - Images of Chlorophyll a : Mean values from satellite imaging from 1998 to 2004 (F. Gohin et M. Huret, 2004)

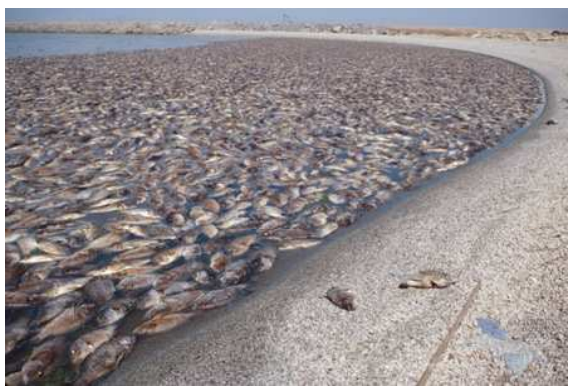

Fig 5 - - Massive death of fishes during low oxygen event in 1982 in the Bay of Vilaine (France)

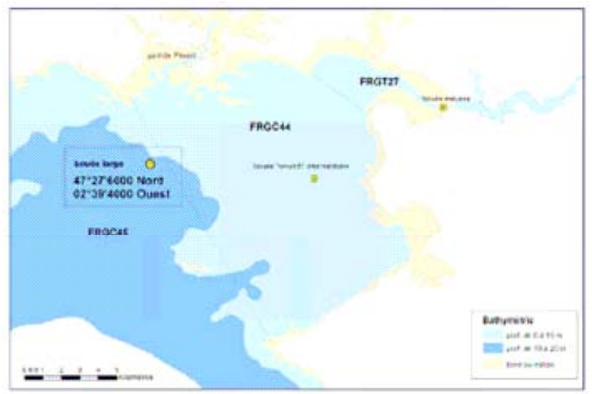

Fig 6- - Three water masses are monitored: estuary (27), transition (44) and coastal (45)

\section{FIRST RESULTS OF 2008 DEPLOYMENT}

The first results in 2008 demonstrated the advantage of hourly automated measurements for the understanding of both algal bloom and oxygen depletion.

The low oxygen level at the seafloor level was threatening the environment of the Bay of Vilaine in May and June. This streng was reduced in July thanks to windy episodes [7].

The monitoring networks in charge of referral to the local and national authorities (REPHY, REMI) used the TROPHIMATIQUE experiment as a warning and a reference data set. It also included in algal bloom monitoring for the shellfish farming network.

The integration into the demonstrator of Operational Oceanography PREVIMER is proving extremely useful and is the basis for the biological panel under construction. Thanks to the positioning of the MOLIT buoy, the data is gathered at a sufficiently long distance from the coast to allow a calibration of the satellite color map. Main events are described in the PREVIMER quarterly newsletter issued on a public portal (http://www.previmer.org/en/newsletter).

GPS positioning is necessary as it appears that the intermediate water site is often visited by fishing vessels and yachts.

A more complete deployment including nutrient analysers (ammonia, nitrate, phosphate and silicate) and an automated sampler is being performed in 2009. The results will be used by the Institution d'Aménagement de la Vilaine for their monitoring plan under the European Water Framework Directive. The conclusions will be reported to the French Ministry for an evaluation of the potential use of automated systems for the monitoring of the main estuaries of France. The input to the models simulating the Gulf of Biscay may become permanent.

\section{ACKNOWLEDGEMENTS}

\section{REFERENCES}

[1] Knauth, H.-D.; Schroeder, F.; Kohnke, D.; Holzkamm, F. - EUROMARMERMAID: experimental operation of the prototype network - OCEANS apos;97. MTS/IEEE Conference Proceedings Volume 1, Issue , Page(s):686 vol. 1 - 6-9 Oct 1997

[2] Woerther, P.; Grouhel, A. - MAREL: automated measurement network for the coastal environment - OCEANS apos;98 Conference Proceedings Volume 2, Issue , 28 Sep-1 Oct 1998 Page(s):1149 - 1154 vol.2 - 1998

[3] Blain S., Guillou J., Tréguer P., Woerther P., Delauney L., Follenfant E., Gontier O., Hamon M., Leildé B., Masson A., Tartu C., Vuillemin R. (2004). "High Frequency Monitoring of Coastal Marine Environment using MAREL buoy". Journal of Environmental Monitoring, 6 (6) 569-575 . 2004

[4] Prien, R.D. (2007), Technologies for new in situ chemical sensors, Oceans '07 IEEE Aberdeen, 18.-22.6.2007, Aberdeen, UK.

[5] Vuillemin R., Le Roux D., Dorval P., Hamon M., Sudreau J.P., Le Gall C., Sarradin P.M. (2007). "CHEMINI, a new generation of in situ chemical analysers for marine applications". European Geosciences Union, Geophysical Research Abstract, Vol. 9, 06213, 15 - 20 April 2007, Vienna, Austria. [6] Schmitt F, SB Zongo Méthodes d'exploitation des mesures à haute fréquence[7] Bouget J.F. Allenou J.P. Information note to authorities : « Teneurs en oxygène dissous en Baie de Vilaine » July 2009.

[8]: F. Lecornu, Yann-Hervé DeRoeck "Coastal observations and forecast" La houille Blanche $\mathrm{N}^{\circ} 12009$

[9] F. Lecornu (IFREMER), Jerome Paillet (SHOM), Hugues Ravel (MeteoFrance) "A Coastal operational forecasting system" SeaTechWeek 2008 Brest (France),

[10] F. Lecornu, Yann-Hervé DeRoeck, Didier Sauzade, Jacques Legrand:"French Coastal Operationnal forecasting system" SFJO 2008 (Japan)

[11] :M Répécaud ${ }^{1}$, Y. Aoustin, S. Barbot, M. Hamon, D. Le Piver, L. Quemener, C. Podeur, R. Vuillemin, K. Bucas, T Rudelle, P. Jegou. "Trophimatique project and chemical analysers (SeaTech Week 2008, Brest) 